\title{
Transforming A Face-To-Face Module For An Online Environment: A Transferable Pedagogical Model
}

\author{
Will Stewart \\ University of Bradford
}

\section{Introduction}

This case study will describe a pedagogical model successfully used in the re-design of an existing faceto-face Postgraduate Certificate in Higher Education Practice (PGCHEP) module for online delivery at the University of Bradford. The challenge was to design a course that reflected a $21^{\text {st }}$-century approach to teaching and learning, rather than simply to replicate a traditional didactic, classroom model in an online setting.

Based around the creation of an online learning community, learning takes place through immersion in this community. Participants are involved in individual and collaborative activities and assessment, structured discussions, synchronous online seminars, sharing of ideas and resources, and critical reflection. The participatory nature of the model encourages peer-to-peer support and allows individuals to contribute their existing expertise to the community as a whole.

The model is enabled through the use of web-based learning technologies, including an online learning platform, blogs, wikis, social bookmarking, communication and collaboration tools. The model allows for flexibility in the choice of tools depending on the nature of the participants and the requirements of the course. Participants are encouraged to develop innovative and creative ways to use these technologies, not only to support their own learning, but that of others in the community. Their use of such a technologyenhanced learning environment is in itself a key learning experience, enabling them to assess its potential for use in their own practice.

It is argued that this pedagogical model is transferable and could be used to transform other face-to-face courses for an online environment.

\section{The context}

The Postgraduate Certificate in Higher Education Practice is designed to support and enhance the practice of lecturers involved in higher education teaching in the UK. It is a Master's level course consisting of $3 \times 20$ credit modules. The online version was designed, in the first instance, specifically for lecturers at the university's partner institutions around the world.

The module has now been delivered twice to staff at one of the university's partner institutions in northwest Pakistan and is currently being delivered to another partner institution in Singapore. There were eight participants in the first presentation and six in the second. In the current presentation there are 14 participants. 


\section{The problem}

In setting out to design this module, our main problem was to ensure that, despite being taught at a distance, the quality of the learning experience of students on the online version was similar or better than that of students on the face-to-face module. In order to ensure equivalence between the face-to-face and the online versions in terms of the learning outcomes, assessment strategies and module topics, it was decided that these would be kept the same. In addition, it was decided to teach the online version over a six-month period, the same duration as the face-to-face module.

Before starting to design the module, there were three major questions that the course team had to address:

1. What design principles would we adopt in order to ensure a high quality learning experience for the students?

2. Which learning platform and other technologies would be the most appropriate for the creation of a learning community?

3. What type of learning activities would encourage students to engage with the module topics?

\section{The major questions addressed}

\section{The design principles}

In designing the online module, the course team agreed that the principles of good teaching that apply to a traditional face-to-face course apply equally to one delivered online. Chickering and Gamson (1987) proposed that good teaching:

1. Encourages contact between students and tutors

2. Develops reciprocity and collaboration amongst students

3. Encourages active learning

4. Gives prompt feedback

5. Emphasises time on task

6. Communicates high expectations

7. Respects diverse talents and ways of learning.

In addition to keeping these teaching principles in mind during the design stage of the module, we also needed to consider how to structure the environment so that students experienced a rich and meaningful learning experience through being active participants in the learning community. Such an environment also needed to consider the nature of the students. These were working professionals with busy teaching schedules, none of whom had taught within the UK higher education system. The design needed to be flexible in terms of time and place, but had also to consider cultural differences. It needed to provide a supportive framework within which students could reflect on their own practice and actively engage not only in their own learning, but also support that of their fellow students.

In terms of models of teaching and learning, it was clear that the final design of the module should most closely align with a constructivist approach, i.e. one where the role of the tutor is to engage participants in authentic learning activities, rather than to act as a deliverer of content, (Biggs and Tang, 2007). It was decided to build the learning experience around the interaction of three essential elements, namely a cognitive element, a teaching element and a social element, as described by Garrison et al., (2000). 


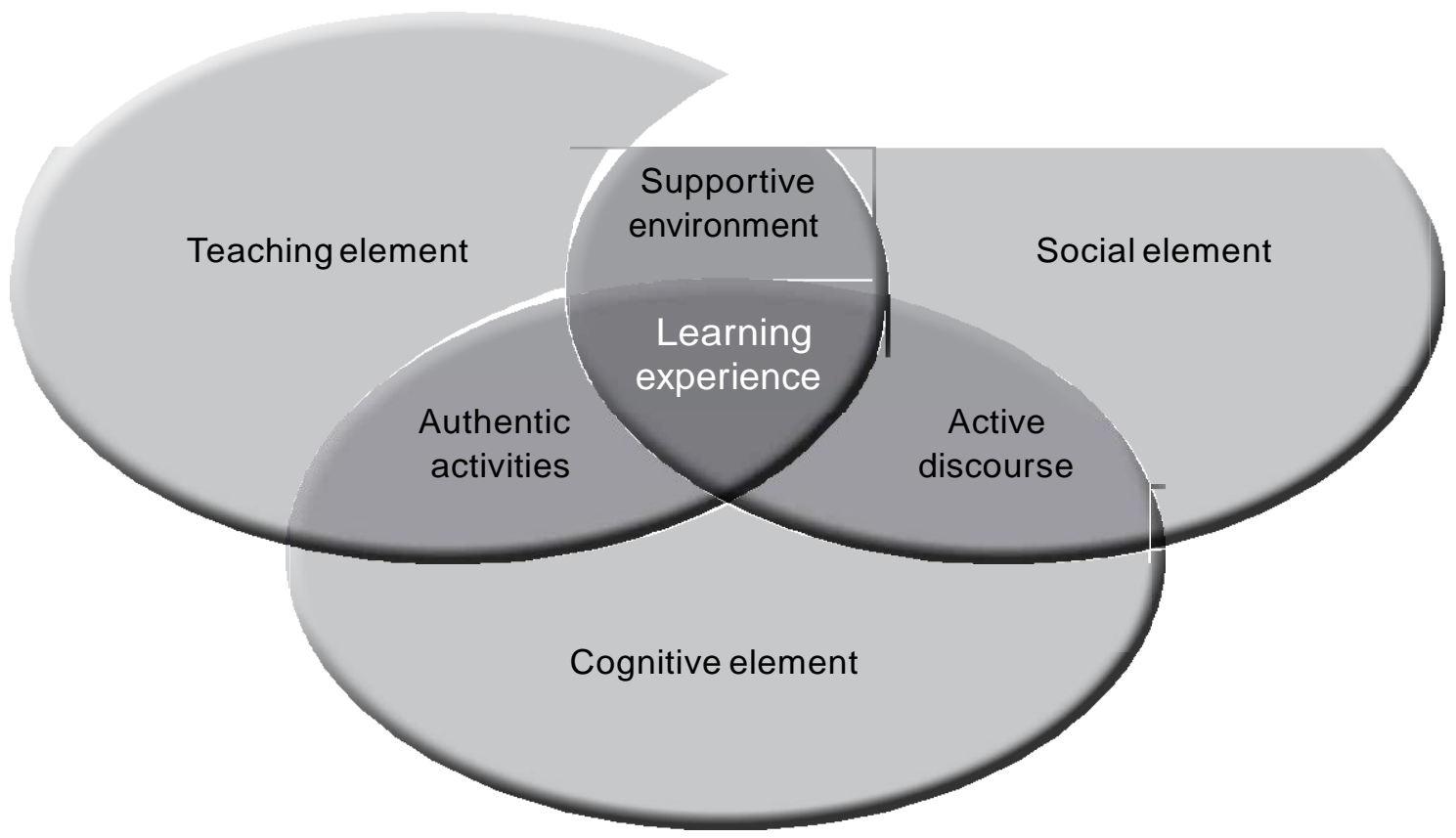

(Adapted from Garrison et al., (2000))

Figure 1 Essential elements of an online learning community

The cognitive element would allow participants to reflect on their own practice, build on existing knowledge, construct new knowledge, and challenge accepted beliefs and practices. It would also enable them to contextualise their learning within their own cultural setting.

The teaching element was made up of two components. The first was important during the development stage and related to the actual design of the learning environment to ensure the active engagement of the students. It was decided that the module would be built around authentic and challenging learning activities, and the provision of opportunities for dialogue and sharing of ideas. As with the assessment, both the learning activities and the discussion were carefully aligned with the learning outcomes. During this development stage, content was sourced or produced that would support the learning activities and help students achieve the learning outcomes.

The second component of the teaching element took place during the delivery of the module and involved the facilitation of learning by the tutors. This required tutors to be visible, to encourage discussion, collaboration and sharing of ideas. In other words, to have a 'presence' (Bach et al., 2007). Students needed to know that the tutors were active members of the community, providing support and guidance whenever needed. If the design is right, students would never feel isolated or alone within the community. Through engagement with the learning activities and discussions, students would make sense of the module content within their own particular context. At no stage in the module was content 'delivered' to students other than in the introductory Blackboard Collaborate session at the start of each topic. There was a clear move away from a traditional didactic approach, where the delivery of content is seen as a tutor's main role, to one where the tutor is much more of a facilitator of learning, as described by McConnell (2000). 
The social element related to the creation of an environment that supports the cognitive and teaching elements through providing a safe and supportive online space in which sharing of ideas, collaboration, dialogue, interaction and reflection can take place. It is this social element that holds the module together and transforms an online space into a learning community.

Designing the module around the interaction of these three essential elements allowed a pedagogical model to be developed that was active, participatory, collaborative and social. Within this framework students are very much interdependent, supporting each other's learning, discussing issues, and helping each other make sense of the theories, practices and topics covered in the module. Their active involvement and critical engagement was key not only to their own learning but also to that of their peers.

Once the pedagogical model and the design of the module had been decided, the next stage was to choose the technologies that would enable both of these to be realised. In this sense it could be argued, that we have transformed the way in which we think about and design a course, accepting that each iteration of the module may involve a modified design and the use of a different suite of technologies. It could also be argued that this model is much more 'learner-centred' than the traditional model where, frequently, an in-house virtual learning environment is used to deliver all courses irrespective of its suitability and functionality.

\section{The learning platform and supporting technologies}

In addressing question 2, it was decided that Moodle would be a more appropriate learning platform than the one currently provided by the university, i.e. Blackboard. Moodle is designed around a social constructivist framework that supports collaboration, interaction and communication in ways that are conducive to the creation of a learning community. It was felt that it would be much more difficult to incorporate the design principles discussed above within Blackboard, and that this would compromise the learning community model we wanted to develop.

A number of other web-based tools were included in the design of the learning community.

Each tool was chosen for its ability to ensure that the seven principles of good teaching could be fully met, and for its contribution towards the three essential elements in the design process. A brief summary of how and why the tools were used is provided in Table 1 below.

Table 1 The use of Web based tools to support the formation of a learning community

\begin{tabular}{|l|l|l|l|l|}
\hline Tool & Use & How it was used & $\begin{array}{l}\text { Main Principles } \\
\text { of Good Teaching } \\
\text { enabled }\end{array}$ & Elements \\
\hline Moodle & $\begin{array}{l}\text { Main learning } \\
\text { platform }\end{array}$ & $\begin{array}{l}\text { Provided the focal point for } \\
\text { the learning community. } \\
\text { It provided the physical } \\
\text { structure and main learning } \\
\text { area. All topics, activities and } \\
\text { other tools were accessed } \\
\text { from here. }\end{array}$ & $1,2,3,4,5,6,7$ & Teaching \\
\hline
\end{tabular}




\begin{tabular}{|c|c|c|c|c|}
\hline Tool & Use & How it was used & $\begin{array}{l}\text { Main Principles } \\
\text { of Good Teaching } \\
\text { enabled }\end{array}$ & Elements \\
\hline $\begin{array}{l}\text { Blackboard } \\
\text { Collaborate } \\
\text { (Elluminate) }\end{array}$ & $\begin{array}{l}\text { Platform for } \\
\text { real-time, } \\
\text { synchronous } \\
\text { seminars }\end{array}$ & $\begin{array}{l}\text { Each topic was introduced } \\
\text { with a Collaborate seminar. } \\
\text { Students also used it to } \\
\text { deliver presentations as } \\
\text { part of a collaborative } \\
\text { assessment. It allowed the } \\
\text { 'face-to-face' component } \\
\text { that is often cited as a } \\
\text { weakness of online learning, } \\
\text { and removed the 'distance' } \\
\text { from distance learning. }\end{array}$ & $1,4,6,7$ & $\begin{array}{l}\text { Teaching } \\
\text { Cognitive } \\
\text { Social }\end{array}$ \\
\hline Skype & $\begin{array}{l}\text { Allowed regular } \\
\text { synchronous, } \\
\text { one-to-one } \\
\text { conversations } \\
\text { with individual } \\
\text { students }\end{array}$ & $\begin{array}{l}\text { This proved invaluable both } \\
\text { for scheduled meetings, } \\
\text { and for the 'can-you-help- } \\
\text { me' chats. It was also used } \\
\text { for scheduled one-to-one } \\
\text { tutorials with individual } \\
\text { students. }\end{array}$ & $1,4,6$ & $\begin{array}{l}\text { Teaching } \\
\text { Cognitive } \\
\text { Social }\end{array}$ \\
\hline Diigo & $\begin{array}{l}\text { Social } \\
\text { bookmarking } \\
\text { site }\end{array}$ & $\begin{array}{l}\text { Allowed students to share } \\
\text { and comment on web- } \\
\text { based resources they felt } \\
\text { were relevant to the module. } \\
\text { The creation and discovery } \\
\text { of resources by students } \\
\text { on an online course is } \\
\text { more common than on } \\
\text { a traditional face-to-face } \\
\text { course, (Anderson and Dron, } \\
2011 \text { ), and is part of being } \\
\text { an active member of the } \\
\text { learning community. }\end{array}$ & 2,3 & $\begin{array}{l}\text { Cognitive } \\
\text { Social }\end{array}$ \\
\hline Wikis & $\begin{array}{l}\text { Collaborative } \\
\text { group work }\end{array}$ & $\begin{array}{l}\text { Students took part in } \\
\text { collaborative group activities } \\
\text { using the wiki tool within } \\
\text { Moodle. Although unfamiliar } \\
\text { with their use, students } \\
\text { quickly learned to use them } \\
\text { effectively and they became } \\
\text { a key learning tool. }\end{array}$ & $2,3,5,6,7$ & $\begin{array}{l}\text { Cognitive } \\
\text { Social }\end{array}$ \\
\hline
\end{tabular}




\begin{tabular}{|l|l|l|l|l|}
\hline Tool & Use & How it was used & $\begin{array}{l}\text { Main Principles } \\
\text { of Good Teaching } \\
\text { enabled }\end{array}$ & Elements \\
\hline Blogs & $\begin{array}{l}\text { Encouraged } \\
\text { reflection on } \\
\text { practice }\end{array}$ & $\begin{array}{l}\text { Students were encouraged } \\
\text { to reflect on their practice } \\
\text { throughout the module, } \\
\text { culminating in a final } \\
\text { assessment which included } \\
\text { an overall reflection of their } \\
\text { journey over the duration of } \\
\text { the module. }\end{array}$ & $3,4,5,7$ & Cognitive \\
& $\begin{array}{l}\text { Students used a variety } \\
\text { of blogs, e.g. Blogger, } \\
\text { Edublogs, to do this, } \\
\text { giving access to the other } \\
\text { participants and allowing } \\
\text { comments. }\end{array}$ & \\
\hline
\end{tabular}

\section{Choice of learning activities}

A key focus of the design framework was to ensure the active involvement and critical engagement of the students in their own learning. Staff teaching on the module would act to facilitate and support students in this goal.

In designing the learning activities to meet both of these requirements, a number of characteristics were kept in mind, namely that the activities should be:

\section{Learner-centric}

Active

\section{Engaging}

\section{Creative}

\section{Purposeful.}

A mix of individual and collaborative activities were designed, and these could be classified into five broad categories, as described in Table 2 below.

Table 2 Categories of individual and collaborative learning activities

\begin{tabular}{|l|l|l|l|}
\hline Category & Description & Example & Individual/collaborative \\
\hline 1 & $\begin{array}{l}\text { Enable students to } \\
\text { contextualise their learning } \\
\text { within their own cultural setting }\end{array}$ & $\begin{array}{l}\text { Create a wiki describing } \\
\text { what makes effective } \\
\text { teaching }\end{array}$ & Collaborative \\
\hline 2 & $\begin{array}{l}\text { Encourage students to } \\
\text { challenge accepted beliefs and } \\
\text { practices }\end{array}$ & $\begin{array}{l}\text { An examination of } \\
\text { assessment in higher } \\
\text { education }\end{array}$ & Individual \\
\hline
\end{tabular}




\begin{tabular}{|l|l|l|l|}
\hline Category & Description & Example & Individual/collaborative \\
\hline 3 & Engage students in a problem & $\begin{array}{l}\text { How to make group work } \\
\text { effective }\end{array}$ & Individual/collaborative \\
\hline 4 & $\begin{array}{l}\text { Highlight specific aspects of } \\
\text { learning goals }\end{array}$ & Exploring effective lecturing & Collaborative \\
\hline 5 & $\begin{array}{l}\text { Encourage students to reflect } \\
\text { on their learning and practice }\end{array}$ & $\begin{array}{l}\text { Development of a personal } \\
\text { learning and teaching } \\
\text { statement }\end{array}$ & Individual \\
\hline
\end{tabular}

The module was designed around seven topics, each one lasting two weeks, with additional time built in for assessment. Each topic was introduced by a one-hour Blackboard Collaborate seminar that all students were required to attend. Pre-reading was provided for these seminars and each one was recorded and made available within the learning community. As well as setting the scene and putting the topic in context, the seminar provided an opportunity for discussion and reflection. This was followed by a two week period during which students worked on a range of individual and collaborative activities, as highlighted in Table 2. Learning took place through their engagement with these activities and through dialogue with peers and tutors in a discussion forum.

\section{Assessment}

The two summative assessments for this module were identical to those of the face-to-face module in terms of what the students were asked to do and the learning outcomes assessed. Assessment 1 was a collaborative assignment in which students were asked to deliver a group presentation that critically analysed a particular educational theory. Their presentation was delivered through Blackboard Collaborate to members of the module team, replicating the situation that students on the face-to-face module experienced. The second assignment was an individual one, reflecting on and evaluating their own teaching practice. In order to emphasise the collaborative nature of the online module, the weighting for each assignment was equal, whereas in the face-to-face module assignment 1 was weighted at only $30 \%$.

Of the 14 students who have completed the module so far (eight in presentation one; six in presentation two), there has been a 100\% pass rate, with 12 receiving merits and two receiving distinctions.

\section{Evaluation}

At time of writing the online version of the learning and teaching in higher education module is in its third presentation. While minor changes to the design have taken place between each presentation, the overall structure of the module has remained stable. Feedback from students from the first two presentations is shown below in Table 3. Each of the questions required a Likert-type response, with five indicating total agreement and one total disagreement.

In general terms, the feedback indicated that the learning community model has worked well in encouraging an active and collaborative approach to learning. For most students, this was their first experience of learning in an online environment and their feedback would indicate that they found it enjoyable and worthwhile. There was some initial concern amongst the course team that, because all participants were from the same institution, this would have a negative effect on the level of engagement. However, the feedback indicated that this did not appear to be the case, and one student commented that: 
"We didn't face any difficulty in engaging with each other in an online environment."

In reflecting on their experience, all students commented that the module had a positive impact on their teaching, helping them to critically evaluate their practice and giving them the confidence to try new methods and technologies with their students. The majority of students (92\%) found the Moodle learning environment enabled the creation of an active online learning community. The use of Blackboard Collaborate (Elluminate) was seen by most (85\%) as a key tool in supporting learning, and a major factor in the success of the module. One student commented:

"Elluminate was the most effective tool we ever used for real-time learning."

All students found the use of Skype as a useful way to make contact with the tutor. It is interesting to note that while Blackboard Collaborate and Skype enabled the synchronous communication component of the module, they were used in completely different ways. Blackboard Collaborate provided the more formal, one-hour, whole-group seminar environment, while Skype was used for more informal one-to-one dialogues between participants and tutors.

From both the tutors' and participants' point of view, the mix of synchronous and asynchronous activities was successful in the sense that it was manageable in terms of time, relevant in terms of student engagement, and effective in terms of student learning. While a 'bedding down' period of between two to four weeks has been typical for participants to familiarise themselves with the technologies, students have adapted well and found the technologies enabling.

Table 3 Participants feedback from first two presentations of module

\begin{tabular}{|l|l|l|l|l|l|}
\hline Survey questions & 5 & 4 & 3 & 2 & 1 \\
\hline Overall I was very satisfied with the module. & $69 \%$ & $23 \%$ & $8 \%$ & - & - \\
\hline $\begin{array}{l}\text { The module provided a flexible, discipline-based and reflective } \\
\text { approach to the practice of teaching and the support of learning. }\end{array}$ & $39 \%$ & $62 \%$ & - & - & - \\
\hline $\begin{array}{l}\text { The module enabled you to engage in a critical reflection of your } \\
\text { current professional activity within your own organisational context. }\end{array}$ & $46 \%$ & $38 \%$ & $16 \%$ & - & - \\
\hline $\begin{array}{l}\text { The module provided you with the support and guidance necessary } \\
\text { to work effectively in an online learning community. }\end{array}$ & $69 \%$ & $31 \%$ & - & - & - \\
\hline $\begin{array}{l}\text { The module developed your knowledge of key concepts in the } \\
\text { field of teaching and learning in HE, and helped you relate these to } \\
\text { effective learning and teaching practice across a range of contexts. }\end{array}$ & $69 \%$ & $23 \%$ & $8 \%$ & - & - \\
\hline $\begin{array}{l}\text { The module examined and evaluated contemporary models, } \\
\text { strategies and techniques to help you design, deliver, manage and } \\
\text { assess your own teaching and your students' learning. }\end{array}$ & $31 \%$ & $62 \%$ & $8 \%$ & - & - \\
\hline
\end{tabular}




\begin{tabular}{|c|c|c|c|c|c|}
\hline Survey questions & 5 & 4 & 3 & 2 & 1 \\
\hline $\begin{array}{l}\text { The module developed your capacity to critically reflect on your } \\
\text { practice, within the context of your own discipline or subject. }\end{array}$ & $46 \%$ & $46 \%$ & $8 \%$ & - & - \\
\hline $\begin{array}{l}\text { The module provided you with an insight into the diversity of } \\
\text { students and of their experiences, and equip you with the } \\
\text { knowledge and skills needed to develop inclusive learning } \\
\text { environments. }\end{array}$ & $8 \%$ & $62 \%$ & $31 \%$ & - & - \\
\hline $\begin{array}{l}\text { The module acted as a platform for your ongoing professional } \\
\text { development. }\end{array}$ & $85 \%$ & $8 \%$ & $8 \%$ & - & - \\
\hline The topics covered in the module were relevant to my own practice. & $46 \%$ & $46 \%$ & $8 \%$ & - & - \\
\hline $\begin{array}{l}\text { The module made good use of information and communications } \\
\text { technology (ICT). }\end{array}$ & $46 \%$ & $54 \%$ & - & - & - \\
\hline $\begin{array}{l}\text { I found the Moodle learning environment an effective space that } \\
\text { helped create an active online learning community. }\end{array}$ & $54 \%$ & $38 \%$ & - & $8 \%$ & - \\
\hline $\begin{array}{l}\text { I found the Blackboard Collaborate (Elluminate) sessions useful in } \\
\text { helping understand the different topics covered in the module. }\end{array}$ & $85 \%$ & - & $16 \%$ & - & - \\
\hline I felt that Skype was a useful tool to enable contact with my tutor. & $69 \%$ & $31 \%$ & - & - & - \\
\hline I found Diigo a useful tool for organising and sharing resources. & $46 \%$ & $23 \%$ & $23 \%$ & $8 \%$ & - \\
\hline
\end{tabular}

$5=$ I totally agree

4 = I mainly agree

$3=1$ neither agree or disagree

2 = I mainly disagree

$1=I$ totally disagree 


\section{Lessons learnt}

1. The success of the module is as much to do with what happens before the start of the course as what happens during it.

Deciding on the design principles and pedagogic model, and then choosing the most appropriate technologies to support that design contributed to the success of the module and enabled a much more learner-centred approach to be adopted than would have been possible using solely 'in-house' tools.

\section{Be explicit and open about the structure and nature of the module before students sign-up for it.}

It is very important that potential students are clear about the structure and nature of the module before they sign up for it. For many, it may be their first experience of an online course, or they may come to the course with preconceived ideas of what it will be like. They should be in no doubt about the learning and teaching strategies used on the module and what this means in terms of their time commitment. Provide students with a study calendar which outlines the start and finish dates for each topic, dates and times of the Blackboard Collaborate seminars, and assignment submission dates. This allows students to plan their time and makes it less likely that they will get behind with their work.

\section{Provide easy navigation through the online environment.}

Navigation through the learning environment should be simple and straightforward. With preferably a single click to move between one page and any other.

\section{Do not assume that students will be familiar with all of the technologies used on the course.}

Many students will have little or no experience of blogs, wikis and Web 2.0 technologies. It is important to build in an induction period during which they can get familiar with the tools to be used on the course. We have found that a two-week induction is about right, during which time they are given a range of tasks to complete that allow them to familiarise themselves with the technology in a non-threatening manner.

\section{Conclusion}

The pedagogical model described in this case study has proved effective in transforming a traditional face-toface module into one suited to an online environment. We feel that we have met our challenge of designing

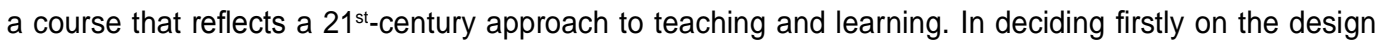
principles and then choosing the most appropriate technology to enable those design principles to be met, meant that the course could be tailored both to the online environment and to the participating students. The focus was on student engagement through authentic learning activities, rather than a tutor-led transmission of content. The development of a learning community resulted in an active, participatory and collaborative approach to learning. Not only is this pedagogical model transferable to other online courses, we would suggest that it could also be incorporated into face-to-face courses with positive effects on the student learning experience.

\section{References}

Anderson, T., and Dron, J. (2011). Three Generations of Distance Education Pedagogy. International Review of Research in Distance and Online Learning, 12 (3), pp. 80-97. 
Bach, S., Haynes, P., and Lewis Smith, J. (2007) Online Learning and Teaching in Higher Education. Maidenhead: Open University Press.

Biggs, J., and Tang, C. (2007) Teaching for Quality Learning at University. Maidenhead: Open University Press.

Chickering, A.W., and Gamson, Z.F. (1987) Seven Principles for Good Practice in Undergraduate Education. American Association of Higher Education Bulletin, 39 (7), pp. 3-7.

Garrison, R., Anderson, T., and Archer, W. (2000) Critical Inquiry in a Text-Based Environment: Computer Conferencing in Higher Education. The Internet and Higher Education, 2 (2-3), pp. 87-105.

McConnell, D. (2000) Implementing Computer Supported Cooperative Learning. London: Kogan Page. 